\title{
Thermophilic Campylobacter spp. in salad vegetables in Malaysia
}

\begin{abstract}
The main aim of this study was to combine the techniques of most probable number (MPN) and polymerase chain reaction (PCR) for quantifying the prevalence and numbers of Campylobacter spp. in ulam, a popular Malaysian salad dish, from a traditional wet market and two modern supermarkets in Selangor, Malaysia. A total of 309 samples of raw vegetables which are used in ulam were examined in the study. The prevalences of campylobacters in raw vegetables were, for supermarket I, Campylobacter spp., 51.9\%; Campylobacter jejuni, 40.7\%; and Campylobacter coli, 35.2\%: for supermarket II, Campylobacter spp., 67.7\%; C. jejuni, 67.7\%; and C. coli, 65.7\%: and for the wet market, Campylobacter spp., 29.4\%; C. jejuni, 25.5\%; and C. coli, 22.6\%. In addition Campylobacter fetus was detected in $1.9 \%$ of raw vegetables from supermarket I. The maximum numbers of Campylobacter spp. in raw vegetables from supermarkets and the wet market were N2400 and $460 \mathrm{MPN} / \mathrm{g}$, respectively.
\end{abstract}

Keyword: Campylobacter, Salad vegetables, Retail outlets 